\title{
PERUBAHAN SISTEM PEMILIHAN KEPALA DAERAH DALAM DINAMIKA PELAKSANAAN DEMOKRASI
}

(Changes of Local Government Election System in Dynamics of Democracy Implementation)

\section{Lutfi Chakim}

Komisi Yudisial Republik Indonesia

Jl. Kramat Raya No. 57, Jakarta Pusat

Email: lutfychakim@gmail.com

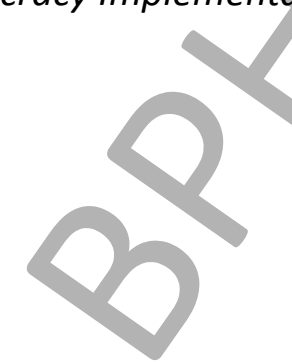

Naskah diterima: 17 Maret 2014; revisi: 14 April 2014; disetujui: 29 April 2014

\begin{abstract}
Abstrak
Pemilihan kepala daerah (pilkada) secara langsung adalah suatu mekanisme yang berfungsi sebagai pelaksanaan demokrasi. Namun, dalam perjalanannya muncul ketidakpuasan berbagai pihak untuk tidak lagi menggunakan sistem pemilihan gubernur secara langsung. Hal itulah yang menjadi dasar bagi Pemerintah untuk mengusulkan sistem pemilihan gubernur oleh Dewan Perwakilan Rakyat Daerah (DPRD) melalui Rancangan Undang-undang tentang Pemilihan Kepala Daerah (RUU Pilkada). Usulan perubahan sistem tersebut merupakan topik yang sangat serius, karena berpotensi mengingkari kedaulatan rakyat yang dijamin dalam UUD 1945. Dengan menggunakan metode penelitian yuridis normatif, dapat disimpulkan bahwa, pertama, pemilihan secara langsung merupakan satu-satunya cara yang paling efektif untuk memaknai frasa "dipilih secara demokratis" sebagaimana dimuat dalam Pasal 18 ayat (4) UUD 1945. Kedua, sejarah pemilihan kepala daerah ditandai dengan diberlakukannya berbagai peraturan perundang-undangan terkait dengan pemerintahan daerah mulai sejak masa kolonial hingga reformasi. Ketiga, sistem pemilihan gubernur secara perwakilan oleh DPRD merupakan kemunduran bagi demokrasi. Oleh karena itu, pemerintah perlu mengambil pelajaran dari sejarah sistem pemilihan kepala daerah. Setelah itu, diharapkan pemerintah dapat meninjau kembali kebijakannya tentang sistem pemilihan kepala daerah oleh DPRD yang tertuang dalam RUU Pilkada.
\end{abstract}

Kata Kunci: Perubahan, Sistem Pemilihan Kepala Daerah, Demokrasi

\begin{abstract}
Local government election directly is a mechanism of democracy implementation. However, it doesn't work as expectation while disappointing parties urge to not use governor election system directly anymore. That's the basis for the Government to propose Governor election system by House of representatives through Draft Law About the local government elections. The proposal to change the system of the local government elections is a very serious topic, because it has to deny the sovereignty of the people in the Republic of Indonesia's 1945 Constitution potentially. Using normative legal research method approach, it could be concluded that, first, government election directly is the most effective way to interpretate the phrase "democratically elected" as mentioned in article 18 verse (4) of the Republic of Indonesia's 1945 Constitution. Second, the history of local government elections marked by the enactment of various regulations on Local Government since the colonial era to the reform. Third, the Governor election system by House of representatives is a setback for democracy. Therefore, the Government needs to learn from the history of local government election. After all, the government expected to review its policy about local government election system by House of representatives in draft Law About the local government elections.
\end{abstract}

Keywords: Change, Local Government Election System, Democracy 


\section{A. Pendahuluan}

Pemilihankepaladaerah(pilkada)merupakan bagian yang sangat penting dari transformasi politik menuju konsolidasi demokrasi lokal yang berujung pada kemampuan membentuk pemerintahan daerah yang representatif, efektif, dan pro-publik. Oleh karena itu, berkualitas atau tidaknya suatu pilkada sangat bergantung pada kerangka hukum seperti apakah yang akan dibentuk. Banyak persoalan dan problematika penyelenggaraan pemilu di Indonesia yang lahir karena kerangka hukum pemilu yang dibuat tidak lebih dari sekedar produk politik transaksional dalam rangka mengamankan kepentingan masing-masing pihak. ${ }^{1}$ Selain itu, parameter domokratis atau tidaknya penyelenggaraan pilkada salah satunya ditentukan oleh sistem pilkada yang demokratis pula, sehingga menjadi harapan agar produk hukum tentang pilkada dapat menghasilkan sebuah sistem pilkada yang demokratis.

Pengaturan terhadap pemilihan kepala daerah dituangkan dalam Pasal 18 ayat (4) UUD Negara Republik Indonesia Tahun 1945 (UUD NRI 1945) yang menentukan bahwa,"Gubernur, Bupati, dan Walikota masing-masing sebagai kepala pemerintah daerah provinsi, kabupaten, dan kota dipilih secara demokratis". Konstitusi secara tegas tidak mengharuskan kepala daerah dipilih secara langsung oleh rakyat, melainkan hanya dipilih secara demokratis. Rumusan "dipilih secara demokratis" dapat bermakna dua, yaitu pertama, bisa dipilih secara langsung oleh rakyat dan kedua, bisa dipilih oleh DPRD sebagai lembaga perwakilan rakyat.
Pasca reformasi, telah terbit 2 (dua) undangundang tentang pemerintahan daerah yang di dalamnya terdapat pengaturan mengenai pemilihan kepala daerah, yakni Undang-Undang Nomor 22 Tahun 1999 Tentang Pemerintah Daerah yang mengatur sistem pemilihan kepala daerah oleh DPRD, yang kemudian diganti oleh Undang-Undang Nomor 32 Tahun 2004 Tentang Pemerintah Daerah yang menentukan sistem pemilihan kepala daerah secara langsung oleh rakyat dan masih berlaku hingga sekarang.

Sejak implementasi sistem pemilihan kepala daerah secara langsung yang dimulai pada tahun 2005, sekarang demokrasi di tingkat lokal mengalami dinamika yang cukup signifikan. Sepanjang periode tersebut masyarakat di tingkat lokal, mulai dari provinsi, kabupaten, kota, dan bahkan di tingkat desa, sibuk memilih pemimpin mereka melalui pemilihan umum. Pemilihan kepala daerah (pilkada) langsung telah menyita perhatian publik, partai politik, dan para kontestan dengan menyedot triliunan rupiah APBD (Anggaran Pendapatan dan Belanja Daerah). ${ }^{2}$

Namun, setelah sekian lama implementasi sistem pemilihan kepala daerah secara langsung yang dimulai dari tahun 2005 hingga sekarang banyak masyarakat Indonesia mempertanyakan, apakah sistem pemilihan kepala daerah khususnya pemilihan Gubernur secara langsung oleh rakyat masih sesuai dengan tujuan demokrasi itu sendiri? Hal itulah yang menjadi dasar bagi Pemerintah mengusulkan Rancangan Undang-undang Pemillihan Kepala Daerah (RUU Pilkada) untuk mengubah sistem pemilihan

Pengantar Redaksi, "RUU Pilkada: Rekayasa Setengah Hati", Jurnal Pemilu dan Demokrasi, Perludem, Edisi 4 November (2012): V.

2 R. Siti Zuhro, "Memahami Demokrasi Lokal: Pilkada, Tantangan dan Prospeknya", Jurnal Pemilu dan Demokrasi, Perludem, Edisi 4 November (2012): 30. 
Gubernur secara langsung oleh rakyat menjadi pemilihan Gubernur oleh DPRD Provinsi. Usulan perubahan sistem pemilihan Gubernur tersebut merupakan topik yang sangat serius, karena mengingat berpotensi mengingkari kedaulatan rakyat yang dijamin dalam UUD 1945.

Diskursus tentang perubahan sistem pemilihan kepala daerah melalui RUU Pilkada menjadi aktual didiskusikan dikalangan masyarakat, sehingga persoalan tersebut menarik untuk dikaji dalam perspektif hukum ketatanegaraan untuk menentukan sistem pemilihan kepala daerah yang demokratis di Indonesia. Oleh karena itu, penulis merasa perlu untuk membahas tema perubahan sistem pemilihan kepala daerah dalam dinamika pelaksanaan demokrasi.

\section{B. Permasalahan}

Mengacu dari latar belakang yang telah diuraikan di atas, maka rumusan masalah adalah sebagai berikut:

1. Bagaimana penafsiran tekstual konstitusi terhadap sistem pemilihan kepala daerah?

2. Bagaimana sejarah sistem pemilihan kepala daerah yang pernah dilaksanakan di Indonesia?

3. Bagaimana sistem pemilihan kepala daerah berdasarkan RUU Pilkada?

\section{Metode Penelitian}

Berdasarkan ruang lingkup serta identifikasi masalah sebagaimana telah diuraikan, maka penelitian ini menggunakan tipe penelitian yuridis normatif (normatif legal research), yaitu penelitian yang ditujukan untuk meneliti asas-asas hukum, sistematika hukum, penelitian terhadap singkronisasi vertikal dan horizontal, perbandingan hukum, dan sejarah hukum. ${ }^{3}$ Penelitian yuridis normatif ini menitikberatkan pada penelitian kepustakaan, karena menggunakan bahan sekunder sebagai sumber utama, seperti peraturan perundangundangan, buku-buku, karya ilmiah dan hasilhasil penelitian yang berkaitan dengan objek penelitian.

Menurut Morris L. Cohen, dalam penelitian hukum terdapat beberapa pendekatan yang digunakan, yaitu statute approach, conceptual approach, analitycal approach, comparative approach, historical approach, philosophical a approach, dan case approach. ${ }^{4}$ Adapun pendekatan yang digunakan dalam penelitian ini adalah pertama, pendekatan historis (historical approach) yang bertujuan untuk mencari latar belakang sejarah pengaturan dan praktek sistem pemilihan kepala daerah di Indonesia. Kedua, pendekatan kompataratif/perbandingan (comparative approach), yaitu membandingkan pemilihan kepala daerah secara langsung oleh rakyat yang diatur dalam Undang-undang Nomor 32 Tahun 2004 tentang Pemerintahan Daerah dan pemilihan Gubernur oleh DPRD yang diatur dalam RUU Pilkada. Ketiga, pendekatan sistem (systematical approach), yaitu pendekatan yang menekankan pada sistem ketatanegaraan dan sistem pemilu yang diterapkan. Keempat, pendekatan peraturan perundang-undangan (statute approach), yaitu bertujuan untuk menelaah dan mengkaji peraturan perundang-

Soerjono Soekanto dan Sri Mamuji, Penelitian Hukum Normatif Suatu Tinjauan Singkat (Jakarta: Rajawali, 2009), hlm. 14.

4 Peter Mahmud Marzuki, Penelitian Hukum (Jakarta: Kencana Prenada Media Group, 2005), hlm. 93. 
undangan yang mengatur tentang pemilihan kepala daerah.

\section{Pembahasan}

\section{Penafsiran Tekstual Konstitusi Terha- dap Sistem Pemilihan Kepala}

Rumusan Pasal 1 ayat (1) UUD 1945 menyatakan, "Negara Indonesia ialah negara kesatuan yang berbentuk republik". Negara kesatuan adalah konsepsi tentang bentuk negara, dan republik adalah konsepsi mengenai bentuk pemerintahan yang dipilih dalam kerangka UUD $1945 .^{5}$ Istilah negara kesatuan (unitary state, eenheidstaat) sebenarnya telah di cantumkan dalam penjelasan umum UUD 1945, yaitu sebagai berikut:

"Dalam pembukaan ini diterima aliran pengertian negara persatuan... Istilah negara persatuan ini tidak menunjukkan bentuk negara, melainkan cita-cita hukum dan cita-cita moral. Artinya ialah negara yang melindungi dan meliputi segenap bangsa seluruhnya. Bentuk negara yang paling cocok untuk mewujudkan cita-cita hukum dan citacita moral negara persatuan itu ialah negara kesatuan. Dalam negara kesatuan tidak ada negara dalam negara, negara dibagi dalam daerah-daerah, tidak terdiri dari negaranegara bagian". ${ }^{6}$

Dalam rangka implementasi dari negara kesatuan yang telah dipilih oleh Indonesia, kemudian keberadaan daerah diatur dalam Pasal 18 ayat (1) UUD 1945 yang menyatakan,
"Negara Kesatuan Republik Indonesia dibagi atas daerah-daerah provinsi dan daerah provinsi itu dibagi atas kabupaten dan kota, yang tiap-tiap provinsi, kabupaten, dan kota itu mempunyai pemerintahan daerah, yang diatur dengan undang-undang." Selain itu, UUD 1945 juga mengakui dan menghormati satuan-satuan pemerintahan daerah yang bersifat khusus atau istimewa serta kesatuan-kesatuan masyarakat hukum adat beserta hak-hak tradisionalnya sepanjang masih hidup, sesuai perkembangan masyarakat dan prinsip Negara Kesatuan Republik Indonesia. Ketentuan Pasal 18 ayat (1) UUD 1945 tersebut jelas mengatur otonomi terletak pada tingkat provinsi dan kabupaten/ kota. Merujuk pada pendapatnya AF Leemans, ${ }^{7}$ model yang diterapkan pada Undang-Undang Nomor 32 tahun 2004 tentang Pemerintahan Daerah adalah, untuk provinsi menggunakan "fused model" yang menempatkan Gubernur sebagai Kepala daerah dan juga sebagai Wakil Pemerintah Pusat di daerah. Sementara untuk Kabupaten/Kota, munggunakan "split model" yang menempatkan Bupati/Wali Kota hanya berkedudukan sebagai Kepala Daerah.

Sementara dalam hal pengisian jabatan kepala daerah Pasal 18 ayat (4) UUD 1945 menentukan bahwa, "Gubernur, Bupati, dan Walikota masing-masing sebagai kepala pemerintah daerah provinsi, kabupaten, dan kota dipilih secara demokratis". Konstitusi secara 
tegas tidak mengharuskan kepala daerah dipilih secara langsung oleh rakyat atau mengharuskan dipilih melalui DPRD, melainkan hanya dipilih secara demokratis. Rumusan "dipilih secara demokratis" lahir dari perdebatan panjang di Panitia Ad Hoc I Badan Pekerja MPR tahun 2000, yaitu antara pendapat yang menghendaki kepala daerah dipilih oleh DPRD dan pendapat lain yang menghendaki dipilih secara langsung oleh rakyat. Namun makna "demokratis" dapat berkonotasi dua yaitu pertama, bisa dipilih secara langsung oleh rakyat dan kedua, bisa dipilih oleh DPRD sebagai lembaga perwakilan rakyat.

Pada saat pembahasan di Panitia Ad Hoc I Badan Pekerja MPR yang mempersiapkan perubahan UUD 1945 pada Tahun 2000, Partai Persatuan Pembangunan telah mengusulkan Pilkada secara langsung, namun hal tersebut tidaklah menjadi keputusan MPR dalam perubahan kedua UUD 1945, yang terbukti bahwa rumusan yang dipilih adalah "dipilih secara demokratis", yang maksudnya adalah memberi kewenangan kepada pembuat undang-undang untuk mempertimbangkan cara yang tepat dalam Pilkada. Pemilihan secara langsung telah ditetapkan untuk memilih Presiden sebagaimana dirumuskan dalam Pasal 6A UUD 1945, hal ini tidak dapat diartikan bahwa Pilkada secara langsung menjadi satusatunya cara untuk memaknai frasa "dipilih secara demokratis" yang dimuat dalam Pasal 18 ayat (4) UUD 1945. Sekiranya hal tersebut menjadi maksud (intent) yang terkandung dalam perubahan pasal UUD 1945 yang bersangkutan, tidaklah terdapat hambatan apapun untuk mengubah Pasal 18 ayat (4) menjadi berbunyi "dipilih secara langsung" pada saat dilakukan perubahan ke-3 UUD 1945 pada tahun 2001, dan tiada satu bukti pun yang membuktikan bahwa pengubah UUD 1945 telah alpa tidak melakukan perubahan Pasal 18 ayat (4) UUD 1945 pada perubahan ke-3 tahun 2001. ${ }^{8}$ Oleh karena itu, rumusan "dipilih secara demokratis" dalam Pasal 18 ayat (4) dibedakan dari rumusan lain yang berlaku untuk pemilihan Presiden, yaitu dipilih secara langsung oleh rakyat.

Jika mencermati rumusan Pasal 18 ayat (4) UUD 1945, maka sebenarnya konstitusi memberikan ruang terbuka kepada pembentuk undang-undang untuk mengatur bagaimana sistem pemilihan kepala daerah, yang pasti harus dilakukan secara demokratis yaitu dapat dilakukan melalui pemilihan langsung oleh rakyat ataupun pemilihan melalui DPRD. Namun demikian, secara umum dikatakan bahwa pemilihan kepala daerah secara langsung oleh rakyat itu lebih demokratis. Karena Pemilu yang demokratis tidak semata mata menentukan siapa yang akan duduk dilembaga pemerintahan, melainkan pemilihan umum yang dapat merepresentasikan kedaulatan rakyat.

\section{Sejarah Sistem Pemilihan Kepala Daerah}

Sejarah pengaturan sistem pemilihan kepala daerah sebenarnya telah ada sejak masa kolonial Belanda yang dituangkan dalam Decentralisatie Wet 1930, pada masa itu sistem pemilihan kepala daerah yang digunakan adalah pengangkatan oleh pemerintah. Jadi jabatan

8 Putusan Mahkamah Konstitusi No. 072-073/PUU-II/2004 tentang Pengujian UU No. 32 Tahun 2004 tentang Pemerintahan Daerah Terhadap UUD 1945. 
Gubernur, Residen dan Asisten Residen dijabat oleh bangsa Belanda, sedangkan jabatan lainnya oleh bangsa Indonesia menggunakan kompensasi upeti. Meneruskan sistem yang telah diwariskan oleh Belanda, pada tanggal 23 November 1945 Pemerintah mengeluarkan Undang-Undang Nomor 1 Tahun 1945 tentang Peraturan Kedudukan Komite Nasional Daerah yang merupakan Undang-Undang Pemerintahan Daerah yang pertama setelah kemerdekaan yang didasarkan pada pasal 18 UUD 1945. Sistem pemilihan kepala daerah yang diatur dalam Undang-Undang Nomor 1 Tahun 1945, yaitu dilakukan dengan cara Pemerintah Pusat menunjuk langsung Kepala Daerah.

Namun, seiring dengan perkembangan, Undang-undang Nomor 1 Tahun 1945 dianggap sudah tidak sesuai lagi dengan semangat kebebasan setelah kemerdekaan. Sehingga pada tanggal 10 Juli 1948 pemerintah mengeluarkan Undang-Undang Nomor 22 Tahun 1948 tentang Pemerintahan di Daerah, yang didalamnya mengatur sistem pemilihan kepala daerah yang masih sama dengan sebelumnya yaitu dengan cara pemerintah pusat menunjuk kepala daerah, dengan rincian untuk calon Gubernur diajukan oleh DPRD kemudian diangkat oleh Presiden, sementara untuk calon Bupati/Walikota diajukan oleh DPRD kemudian diangkat oleh Mendagri.

Sistem pemilihan kepala daerah berdasarkan Undang-Undang Nomor 22 Tahun 1948 dianggap sudah tidak sesuai lagi, sehingga direvisi dengan Undang-Undang Nomor 1 Tahun 1957 tentang Pokok-pokok Pemerintahan Daerah, perubahan tersebut merupakan aspirasi dari partai politik di Parlemen yang menuntut adanya pemerintah daerah yang lebih demokratis. Sistem pemilihan kepala daerah yang dterapkan yaitu dengan cara pemilihan langsung. Namun, sayangnya sistem pemilihan langsung yang berdasarkan Undang-Undang Nomor 1 Tahun 1957 tersebut belum sempat di laksanakan, karena keadaan yang telah menimbulkan keresahan di kalangan Pamong Praja yang bertugas melaksanakan urusan-urusan pemerintah pusat di daerah.

Perkembangan selanjutnya, sebagai tindak lanjut dari Dekrit Presiden, pada tanggal 16 November 1959 Pemerintah mengeluarkan Penetapan Presiden Nomor 6 Tahun 1959 Tentang Pengangkatan Kepala Daerah untuk mengatur Pemerintahan Daerah agar sejalan dengan UUD 1945. Dalam Penetapan Presiden Nomor 6 Tahun 1959 tersebut sistem pemilihan kepala daerah yaitu Kepala Daerah diusulkan oleh DPRD, tapi diangkat oleh Presiden untuk Daerah Tingkat I, dan oleh Menteri Dalam Negeri untuk Kepala Daerah Tingkat II. Seolah masih belum juga menemukan pengaturan yang tepat tentang Pemerintahan Daerah, sehingga pada pertengahan dekade tahun 1960 telah timbul tuntutan yang semakin kuat untuk merevisi sistem Pemerintahan Daerah agar sejalan dengan semangat Demokrasi Terpimpin dan Nasakom (kelompok partai Nasionalis, Agama dan Komunis). Perubahan tersebut kemudian dituangkan dalam Undang-Undang Nomor 18 Tahun 1965 Tentang Pokok-Pokok Pemerintahan Daerah, tetapi masih menggunakan sistem pemilihan kepala daerah yang sama dengan sebelumnya, yaitu diangkat oleh Presiden untuk Daerah Tingkat I, dan oleh Menteri Dalam Negeri untuk Kepala Daerah Tingkat II.

Kemudian pada masa Orde Baru, sebagai tindak lanjut dari peristiwa G 30 S PKI yang kemudian diikuti dengan lahirnya masa Orde Baru, pemerintah mengeluarkan UndangUndang Nomor 5 Tahun 1974 Tentang PokokPokok Pemerintahan di Daerah, UndangUndang tersebut mengatur sistem pemilihan 
kepala daerah dengan cara pencalonan oleh Fraksi di DPRD yg memenuhi syarat, kemudian menominasikan calon kepala daerah tersebut kepada Presiden dan kemudian diputuskan dan diangkat oleh Presiden.

Setelah Indonesia memasuki masa reformasi pada tahun 1998, aspirasi mengenai otonomi daerah (otoda) dan desentralisasi muncul melalui sidang MPR tahun 1998 yang dituangkan dalam ketetapan MPR Nomor XV/MPR/98 tentang "Penyelenggaraan Otonomi Daerah; Pengaturan, Pembagian, dan Pemanfaatan Sumber Daya Nasional yang Berkeadilan; dan Perimbangan Keuangan Pusat dan Daerah dalam Kerangka Mempertahankan dan Memperkokoh Negara Kesatuan RepublikIndonesia". Kemudian, secara eksplisit, Pasal 7 Ketetapan MPR Nomor XV/MPR/1998 memerintahkan untuk pelaksanaan pembaruan dalam pelaksanaan pemerintahan daerah dengan Undang-undang. Untuk melaksanakan ketetapan MPR tersebut, pemerintah mengesahkan Undang-Undang Nomor 22 Tahun 1999 tentang Pemerintahan Daerah dan Undang-Undang Nomor 25 Tahun 1999 tentang Perimbangan Kekuasaan antara Pemerintah Pusat dan Daerah. Kedua UndangUndang tersebut dianggap sebagai cetak biru desentralisasi dan otonomi daerah di Indonesia. Meskipun begitu, perlu dicatat bahwa kedua Undang-Undang tersebut dipersiapkan dalam waktu yang sangat singkat dan tampaknya tidak mengacu pada grand design yg seharusnya menyatakan bagaimana arah otonomi daerah itu sendiri. Dalam Pasal 34 ayat (1) UndangUndang Nomor 22 Tahun 1999 mengatur terkait dengan sistem pemilihan kepala daerah yang menyatakan, bahwa pemilihan atau pengisian jabatan Kepala Daerah dan Wakil Kepala Daerah (Gubernur, Bupati, dan Walikota) dilakukan oleh DPRD melalui pemilihan secara bersamaan.
Namun, ternyata sistem pemilihan tersebut menutup akses orang-orang terbaik di daerah untuk menjadi pemimpin dan justru melahirkan rezim korup di daerah.

Oleh karena itu, pada tahun 2004 dilakukannya revisi melalui disahkannya Undang-Undang Nomor 32 Tahun 2004 tentang Pemerintahan Daerah yang memberi kewenangan lebih luas kepada daerah untuk mengatur rumah tangganya sendiri dan dalam menyelenggarakan pemerintahan. Namun setelah sekian lama implementasi Undang-Undang Nomor 32 Tahun 2004 tentang Pemerintahan Daerah mulai dari tahun 2004 hingga sekarang, masyarakat menilai Undang-Undang Nomor 32 Tahun 2004 tentang Pemerintahan Daerah juga masih menyimpan banyak kekurangan dan kelemahan yang menyebabkan kerancuan dalam sistem pemerintahan dan ketatanegaraan. Hal ini didasarkan pada kenyataan bahwa pelaksanaan otonomi di bawah Undang-Undang Nomor 32 Tahun 2004 tentang Pemerintahan Daerah salah satunya menghadirkan politik dinasti dan politik transaksi sehingga berakibat maraknya praktek korupsi kolusi nepotisme (KKN) yang menghasilkan "raja-raja kecil" di daerah. Selain itu, berbagai masalah terkait dengan pemerintahan daerah juga banyak terjadi mulai dari pembentukan daerah otonom baru yang berkembang pesat, permasalahan terkait dengan pemilihan kepada daerah, sampai permasalahan terkait dengan desa.

Salah satu persoalan akibat implementasi dari Undang-Undang Nomor 32 Tahun 2004 tentang Pemerintahan Daerah adalah terkait dengan pemilihan kepala daerah, khususnya pemilihan Gubernur secara langsung oleh rakyat. Sehingga usulan untuk perubahan sistem pemilihan kepala daerah khususnya pemilihan gubernur mulai bergulir sejalan 
dengan banyaknya ketidakpuasan berbagai pihak untuk tidak lagi menggunakan sistem pemilihan gubernur secara langsung oleh rakyat. RUU Pilkada yang merupakan bagian dari revisi Undang-undang Nomor 32 Tahun 2004 tentang Pemerintahan Daerah yang di dalamnya mengatur pemilihan gubernur secara langsung. Saat ini, RUU Pilkada sedang dalam proses pembahasan oleh DPR sebagai bagian dari program legislasi nasional.
Dinamika perkembangan pemerintahan daerah tersebut tidak terlepas dari sejarah sistem pemilihan kepala daerah. Adanya perubahan sistem pemilihan kepala daerah di Indonesia ditandai dengan telah diberlakukannya berbagai peraturan perundang-undangan terkait dengan Pemeritahan Daerah. Dalam konteks sejarah pemilihan kepala daerah, beberapa sistem pemilihan kepala daerah telah dilaksanakan, lebih lanjut akan dijelaskan dalam tabel berikut ini.

Tabel 1. Sejarah Sistem Pemilihan Kepala Daerah

\begin{tabular}{|c|c|c|c|c|}
\hline No. & Masa & Dasar Hukum & em & Keterangan \\
\hline 1. & Kolonial & Decentralisatie Wet 1930 & Pengangk & $\begin{array}{l}\text { Gubernur, Residen dan Asisten Residen } \\
\text { dijabat oleh Orang Belanda. Sedangkan } \\
\text { jabatan lainnya oleh Bangsa Indonesia } \\
\text { dgn kompensasi upeti }\end{array}$ \\
\hline \multirow[t]{5}{*}{2.} & \multirow[t]{5}{*}{ Kemerdekaan } & $\begin{array}{l}\text { Undang-Undang Nomor } 1 \\
\text { Tahun } 1945 \text { tentang Peraturan } \\
\text { Kedudukan Komite Nasional } \\
\text { Daerah }\end{array}$ & Pengangkatan & $\begin{array}{l}\text { Kepala Daerah merangkap sebagai } \\
\text { Badan Perwakilan Daerah }\end{array}$ \\
\hline & & $\begin{array}{l}\text { Undang-Undang Nomor } \\
22 \text { Tahun } 1948 \text { tentang } \\
\text { Pemerintahan di Daerah }\end{array}$ & Pengangkatan & $\begin{array}{l}\text { 1. Calon Gubernur diajukan oleh } \\
\text { DPRD kemudian diangkat oleh } \\
\text { Presiden; } \\
\text { 2. Calon Bupati/Walikota diajukan } \\
\text { oleh DPRD kemudian diangkat } \\
\text { oleh Mendagri. }\end{array}$ \\
\hline & & $\begin{array}{l}\text { Undang-Undang Nomor Tahun } \\
1957 \text { tentang Pokok-pokok } \\
\text { Pemerintahan Daerah }\end{array}$ & Pemilihan langsung & Belum sempat di laksanakan \\
\hline & & $\begin{array}{l}\text { Penetapan Presiden Nomor } \\
6 \text { Tahun } 1959 \text { tentang } \\
\text { Pengangkatan Kepala Daerah }\end{array}$ & Pengangkatan & $\begin{array}{l}\text { Kepala Daerah diangkat oleh Presiden/ } \\
\text { Mendagri }\end{array}$ \\
\hline & & $\begin{array}{l}\text { Undang-Undang Nomor } 18 \\
\text { Tahun } 1965 \text { tentang Pokok- } \\
\text { Pokok Pemerintahan Daerah }\end{array}$ & Pengangkatan & $\begin{array}{l}\text { Kepala Daerah diangkat oleh Presiden/ } \\
\text { Mendagri }\end{array}$ \\
\hline 3. & Orde Baru & $\begin{array}{l}\text { Undang-Undang Nomor } 5 \\
\text { Tahun } 1974 \text { Tentang Pokok- } \\
\text { Pokok Pemerintahan di Daerah }\end{array}$ & Pengangkatan & $\begin{array}{l}\text { Pencalonan oleh Fraksi yg memenuhi } \\
\text { syarat Kepala Daerah diangkat oleh } \\
\text { Presiden. }\end{array}$ \\
\hline \multirow[t]{2}{*}{4.} & \multirow[t]{2}{*}{ Reformasi } & $\begin{array}{l}\text { Undang-Undang Nomor } \\
22 \text { Tahun } 1999 \text { Tentang } \\
\text { Pemerintah Daerah }\end{array}$ & $\begin{array}{l}\text { Perwakilan } \\
\text { (Pemilihan oleh } \\
\text { DPRD) }\end{array}$ & $\begin{array}{l}\text { Pencalonan oleh fraksi yang memenuh } \\
\text { syarat }\end{array}$ \\
\hline & & $\begin{array}{l}\text { Undang-Undang Nomor } \\
32 \text { Tahun } 2004 \text { tentang } \\
\text { Pemerintah Daerah }\end{array}$ & Pemilihan langsung & $\begin{array}{l}\text { Pencalonan oleh Parpol parlemen/non } \\
\text { parlemen dan perseorangan }\end{array}$ \\
\hline
\end{tabular}

Sumber: Ida Budhiati, "Reformasi Bidang Politik Menuju Penguatan Demokrasi Lokal", KPU Jawa Tengah, idabudhiati.files. wordpress.com, (diakses pada 15 Maret 2014). 
Berdasarkan tabel di atas, beberapa sistem pemilihan kepala daerah mulai dari masa kolonial hingga reformasi pernah diterapkan di Indonesia, pengalaman itu cukup memberikan pelajaran bagi Indonesia untuk selanjutnya menentukan sistem pemilihan kepala daerah yang tepat dan tentunya berdasarkan prinsipprinsip demokrasi. Sehingga evaluasi terhadap sistem pemilihan kepala daerah yang pernah diterapkan di Indonesia menjadi sangat penting, setidaknya didasari alasan: ${ }^{9}$

1. Penggunaan sistem pemilihan kepala daerah memiliki pengaruh yang sangat besar terhadap proporsionalitas hasil pemilihan;

2. Sistem pemilihan mempunyai pengaruh terhadap jenis pemerintahan yang akan terbentuk dalam pemilukada. Penggunaan sistem distrik dianggap adapat menjamin munculnya pemerintahan yang lebih menjamin munculnya pemerintahan yang lebih populer dikalangan masyarakat lokal, sementara penggunaan sistem proporsional hanya akan menghasilkan pemerintahan yang tidak dikenal rakyat;

3. Sistem pemilihan kepala daerah langsung juga mempengaruhi corak dan karakter partai politik;

4. Sistem pemilihan kepala daerah juga berpengaruh terhadap corak kompetisi dalam pemilukada;

5. Penggunaan sistem pemilihan kepala daerah juga sangat menentukan karakter pemerintahan yang dihasilkan;

6. Sistem pemilihan kepala daerah berpengaruh juga terhadap akuntabilitas pemerintahan yang dibentuknya;
7. Sistem pemilihan kepala daerah juga berpengaruh terhadap tingkat kohesi partaipartai dalam pemilukada;

8. Sistem pemilihan berpengaruh terhadap wujud partisipasi rakyat dalam pemilihan.

\section{Sistem Pemilihan Kepala Daerah Berdasarkan RUU Pilkada}

\section{a. Perubahan Sistem Pemilihan Kepala Daerah}

Adanya perdebatan tentang perubahan sistem pemilihan kepala daerah khususnya pemilihan gubernur mulai bergulir sejalan dengan banyaknya ketidakpuasan berbagai pihak untuk tidak lagi menggunakan sistem pemilihan gubernur secara langsung oleh rakyat. Usulan terhadap perubahan sistem pemilihan gubernur mencuat ketika Pemerintah melalui Kementerian Dalam Negeri (Kemendagri) mengusulkan RUU Pilkada. RUU Pilkada ini merupakan bagian dari revisi Undang-Undang Nomor 32 Tahun 2004 tentang Pemerintahan Daerah yang di dalamnya mengatur pemilihan gubernur secara langsung oleh rakyat. Saat ini, RUU Pilkada sedang dalam proses pembahasan oleh DPR dan menjadi bagian dari program legislasi nasional (prolegnas).

Dalam RUU Pilkada tersebut, Pemerintah mengajukan usulan perubahan sistem pemilihan Gubernur, yaitu merubah sistem pemilihan Gubernur secara langsung oleh rakyat menjadi sistem pemilihan Gubernur secara perwakilan oleh DPRD Provinsi. Sebagaimana dijelaskan dalam Pasal 2 RUU Pilkada yang menyatakan, "Gubernur dipilih oleh DPRD Provinsi secara

\footnotetext{
9 Gregorius Sahdan dan Muhtar Haboddin (Editor), Evaluasi Kritis Penyelenggaraan Pilkada di Indonesia (The Indonesian Power for Democracy (IPD), 2009), hlm. 2-4 dalam Ni'matul Huda, Dinamika Ketatanegaraan Indonesia dalam Putusan mahkamah Konstitusi (Yogyakarta: FH UII Press, 2011), hlm. 197.
} 
demokratis berdasar asas bebas, rahasia, jujur, dan adil". Perubahan sistem pemilihan Gubernur tersebut juga berimplikasi terhadap penyelenggara pemilihan Gubernur, Pasal 5 RUU Pilkada menjelaskan bahwa, "Penyelenggara Pemilihan Gubernur adalah: $a$. KPU Provinsi; b. DPRD Provinsi". KPU Provinsi disini bertugas untuk melaksanakan kegiatan pengumuman pendaftaran calon Gubernur, penelitian persyaratan calon Gubernur, dan penetapan calon Gubernur. Sementara DPRD Provinsi bertugas untuk melaksanakan kegiatan penyampaian visi dan misi, pemungutan dan penghitungan suara, penetapan hasil pemilihan dan penyampaian keberatan (Pasal 5 ayat (2) dan (3) RUU Pilkada).

Gagasan pemerintah yang mengusulkan pemilihan Gubernur oleh DPRD melalui RUU Pilkada tersebut setidaknya masih menimbulkan pro dan kontra dikalangan masyarakat. Bagi pihak yang pro, sedikitnya ada dua alasan khusus untuk yang setuju dengan pemerintah dalam hal usulan pemilihan gubernur oleh DPRD. Pertama, yaitu untuk meningkatkan efisiensi anggaran pemilu yang memiliki biaya yang sangat tinggi untuk proses pemilihan Gubernur.

Bahkan Menteri Dalam Negeri Gamawan Fauzi pernah menyatakan ${ }^{10}$, bahwa setiap calon yang ingin menjalankan dalam pemilihan gubernur langsung membutuhkan setidaknya lebih dari Rp 20 miliar atau sekitar US \$ 2 juta. Sementara itu, gaji pokok gubernur sebesar Rp 8,7 juta per bulan, kalau mau menjadi seorang Gubernur membutuhkan uang Rp 20 miliar, dengan gaji gubernur sebesar Rp 8,7 juta per bulan, maka butuh waktu berapa lama untuk mengembalikan uang $\mathrm{Rp} 20$ miliar itu? Oleh karena itu, munculnya kekhawatiran akan terjadinya korupsi akan sangat besar, mengingat kandidat berpotensi mencari cara apapun agar uang mereka yang dikeluarkan selama proses kampanye dapat kembali. Kedua, bahwa gubernur hanya memiliki tingkat otoritas yang rendah. Rendahnya intensitas hubungan antara gubernur dan masyarakat tidaklah menuntut akuntabilitas yang tinggi dari gubernur kepada masyarakat. Oleh karena itu, Pemerintah mencatat, bahwa proses pemilihan langsung akan terlalu mahal hanya untuk pemilihan gubernur karena otoritas mereka hanya sebagai wakil pemerintah pusat di tingkat daerah. Kalau kewenangan Gubernur sangat terbatas, mengapa harus dipilih dengan biaya yang sangat mahal?.

Berbeda juga alasan bagi pihak yang kontra terhadap usulan pemilihan gubernur oleh DPRD menyatakan, bahwa pemilihan gubernur oleh DPRD adalah merupakan suatu kemunduran yang luar biasa bagi demokrasi di Indonesia. Karena Pemilihan Gubernur oleh DPRD tidak mencerminkan kedaulatan rakyat, sebagaimana dijamin dalam Pasal 1 ayat (2) UUD 1945. Masyarakat luas tidak tahu track record dan bagaimana visi dan misi para calon Gubernur mereka, artinya DPRD menjadi sebagai kekuatan dominan yang akan membajak hak konstitusional rakyat untuk berpartisipasi dalam pemerintahan.

Sementara untuk sistem pemilihan Bupati/ Walikota, yaitu tetap mengggunakan sistem pemilihan langsung oleh rakyat. Sebagaimana dijelaskan dalam Pasal 41 RUU Pilkada yang 
menyatakan, "Pemilihan Bupati/Walikota dilaksanakan secara demokratis berdasarkan asas langsung, umum, bebas, rahasia, jujur, dan adil".

Kemudian bagaimana untuk sistem pemilihan wakil kepala daerah?. Di dalam RUU Pilkada hanya mengatur sistem pemilihan Gubernur dan Bupati/Walikota, sementara untuk mekanisme pemilihan wakil kepala daerah (Wakil Gubernur dan Wakil Bupati/ Walikota) tidak lagi dipilih secara berpasangan dengan kepala daerah, tetapi wakil kepala daerah diusulkan oleh kepala daerah terpilih yang berlatar belakang dari Pegawai Negeri Sipil (PNS). Hal itu dimaksudkan untuk menghindari fenomena "pecah kongsi" yang mengakibatkan tidak efektifnya penyelenggaraan pemerintahan daerah.

Berkaitan dengan eksistensi wakil kepala daerah, naskah akademik RUU Pilkada menyatakan, apakah jabatan wakil kepala daerah masih diperlukan? Kalau iya, apakah calon wakil kepala daerah dipilih atau diangkat? Dalam pemilihan atau pengangkatan tersebut, apakah calon wakil kepala daerah berpasangan dengan kepala daerah atau tidak? Jawaban terhadap beberapa pertanyaan tersebut sebagian telah terjawab dari praktek pemilihan atau pengangkatan wakil kepala daerah sebagaimana telah diatur dalam sejarah pemerintahan daerah di Indonesia. Jawaban lain dapat dikemukakan sebagai berikut: ${ }^{11}$

1. Jabatan wakil kepala daerah tidak diisyaratkan dalamUUD. Artinya, keberadaan jabatan ini tidak bersifat imperative. Apabila akan diadakan, pengaturannya tergantung pada UU yang mengaturnya.
2. Undang-undang umumnya mengatur bahwa wakil kepala daerah bertanggungjawab kepada kepala daerah. Pengaturan tanggungjawab tersebut menunjukkan kedudukan yang tidak sama antara kepala daerah dan wakil kepala daerah, dan bahkan menyiratkan posisi sebagai subordinate.

3. Posisi yang tidak setara dan cenderung bersifat subordinate mengingatkan bahwa calon kepala daerah dan wakil kepala daerah selayaknya tidak dicalonkan berpasangan. Pencalonan yang demikian itu memberikan beban moral dan sumberdaya yang besar bagi calon wakil kepala daerah untuk memenangkan pilkada. Dalam konteks ini, pemenangan pilkada merupakan beban bersama bagi pasangan calon. Padahal pada saat kemenangan diperoleh, dan pasangan calon tersebut dilantik, hubungan di antara keduanya tidak lagi bersifat kemitaraan tetapi sudah menjadi hierarkis.

4. Kalau jabatan wakil kepala daerah diadakan dengan tujuan utama untuk membantu kepala daerah dapat dengan optimal melaksanakan tugasnya, maka perlu dipertimbangkan bahwa setiap kepala daerah memiliki kepribadian dan gaya kepemimpinan masing-masing. Hubungan kerja yang harmonis antara kepala daerah dan wakil kepala daerah sebagian besar akan dipengaruhi oleh penilaian kepala daerah terhadap motivasi dan gaya kerja wakil kepala daerah. Dalam konteks ini, pencalonan wakil kepala daerah semestinya bermula dari kepala daerah yang membutuhkan wakil kepala daerah.

\footnotetext{
11 Lihat Naskah Akademik Tentang Rancangan Undang-undang Tentang Pemilihan Kepala Daerah (RUU Pilkada).
} 
5. Pencalonan wakil kepala daerah oleh kepala daerah terpilih memunculkan status jabatan wakil kepala daerah, dengan dua opsi, yakni: administrative career atau political appointee. Sebagai administrative career, rekrutmen wakil kepala daerah akan berupa pengangkatan dan berasal dari kalangan pegawai negeri, sedangkan sebagai political appointee, rekrutmennya akan berupa pemilihan oleh DPRD dan dapat berasal dari semua kalangan. Apa pun pilihan alternative rekrutmennya, karena wakil kepala daerah dicalonkan oleh kepala daerah terpilih, maka masa jabatannya sama dengan masa jabatan kepala daerah terpilih yang mencalonkannya. Pada saat kepala daerah berhalangan tetap, maka berakhir juga masa jabatan wakil kepala daerah.

6. Hubungan pribadi kepala daerah dengan wakil kepala daerah di kebanyakan daerah tidak harmonis. Perlu menentukan satu dari dua pilihan. Pertama, pencalonan wakil kepala daerah dilakukan bersamaan dengan pencalonan kepala daerah oleh partai politik/gabungan partai politik/kalangan masyarakat pendukung. Kedua, calon wakil kepala daerah ditentukan oleh calon kepala daerah, dan sebaiknya dari parpol yang sama. ${ }^{12}$

Penjelasan tentang eksistensi wakil kepala daerah yang terdapat dalam naskah akademik RUU pilkada tersebut setidaknya menjelaskan bahwa UUD 1945 hanya mengatur keberadaan provinsi, kabupaten/kota masing-masing akan dipimpin oleh Gubernur, Bupati/Walikota. Rekrutmen Gubernur, Bupati/Walikota yang masing-masing dipilih secara demokratis. Akan tetapi, UUD 1945 tidak mengatur tentang keberadaan Wakil Gubernur, Wakil Bupati/ Wakil Walikota.

\section{b. RUU Pilkada: Kemunduran Demokrasi Lokal}

Istilah demokrasi menurut asal kata berarti rakyat yang berkuasa atau government by the people, (kata yunani demos berarti rakyat, kratos/kratein berarti kekuasaan/berkuasa. ${ }^{13}$ Jadi demokrasi merupakan gagasan yang mengandaikan bahwa kekuasaan itu adalah dari, oleh dan untuk rakyat. Dalam pengertian yang partisipatif demokrasi bahkan disebut sebagai kekuasaan dari, oleh dan bersama rakyat. Dan oleh karena itu, rakyatlah yang menentukan dan memberi arah serta yang sesungguhnya menyelenggarakan kehidupan kenegaraan. ${ }^{14}$

Dalam rangka pelaksanaan demokrasi maka diadakan yang namanya pemilihan umum, melalui pemilihan umum pula diharapkan rakyat dapat terlibat langsung dalam menentukan pemimpinnya baik di pusat maupun di daerah. Namun demikian, jika melihat usulan pemerintah tentang sistem pemilihan Gubernur melalui DPRD yang tertuang pada RUU Pilkada bukanlah merupakan sebuah kebijakan yang tepat, sehingga dapat mengingkari prinsip demokrasi. Hal itu cukup beralasan, setidaknya terdapat beberapa faktor yang

Ibid.

Miriam Budiardjo, Dasar-dasar Ilmu Politik (Jakarta: PT Gramedia Pustaka Utama, 2010), hlm. 105.

14 Jimly Assidiqie, Hukum Tata Negara dan Pilar-Pilar Demokrasi, Serpihan Pikiran Hukum, Media dan HAM (Jakarta: Konstitusi press, 2005), hlm. 241. 
dapat mementahkan alasan pemerintah untuk mengusulkan pemilihan Gubernur melalui DPRD, yaitu sebagai berikut:

1. Pemilihankepala daerah tidaklangsung dapat mengingkari kedaulatan rakyat yang dijamin dalam Pasal 1 ayat (2) UUD 1945, rakyat tidak mengetahui bagaimana track record, visi dan misi calon, karena mereka tidak memiliki kesempatan untuk berpartisipasi langsung dalam menyampaikan aspirasi mereka terhadap calon kepala daerah.

2. Pemilihan kepala daerah tidak langsung juga bertentangan dengan Pasal 28D ayat (3) UUD 1945 yang mengatakan, "Setiap warga negara berhak memperoleh kesempatan yang sama dalam pemerintahan". Karena dengan sistem tersebut tidak memungkinkan bagi calon independen untuk memiliki kesempatan dalam mencalonkan diri sebagai kepala daerah. Sehingga rakyat tidak memiliki banyak pilihan yang sesuai dengan kriteria mereka.

3. Sebuah kemunduran bagi demokrasi di Indonesia. Karena jika kepala daerah dipilih melalui DPRD, maka akan kembali kepada masa lalu yang justru berpotensi menimbulkan transaksi-transaksi politik yang kotor di DPRD.

4. Apabila muncul alasan bahwa pemilihan kepala daerah Oleh DPRD adalah untuk menghemat biaya, maka bukan merupakan alasan yang tepat, karena sangat tidak rasional jika hanya dengan alasan dapat menghemat biaya tapi justru berpotensi menimbulkan transaksi politik kotor di DPRD dan dapat mengurangi hak konstitusional warga Negara untuk berpartisipasi dalam pemerintahan, yaitu hak konstitusional warga negara untuk memilih dan dipilih (rights to vote and rights to be candidate). Oleh karena tu, sebenarnya yang harus dilakukan adalah memperbaiki sistem yang kebal adanya Korupsi, Kolusi dan Nepotisme.

Berdasarkan alasan diatas, maka terlalu cepat jika pemerintah menilai bahwa sistem pemilihan kepala daerah secara langsung telah gagal dan tidak efektif. Berdasarkan pengalaman, melalui UU No. 32 tahun 2004 dan baru dimulai pada tahun 2005 Indonesia menerapkan pemilihan kepala daerah secara langsung, terhitung baru 10 tahun sistem tersebut diterapkan, sehingga itu merupakan waktu yang sangat singkat untuk menilai gagalnya sebuah sistem. Seharusnya pemerintah perlu untuk mengevaluasi jika ada kekurangan guna memperbaiki sistem, bukan malah merubahnya.

Membangun negara dengan nilai-nilai demokrasi penuh tidak bisa didapat secara instan tetapi perlu proses. Orang harus diberi kesempatan untuk belajar dari kelemahan mereka dalam menjalankan pemilihan langsung di masa lalu. Jika Pemerintah dan DPR sepakat untuk kembali ke mekanisme lama pemilihan gubernur, maka akan menjadi kemunduran bagi konsolidasi demokrasi kita. Oleh karena itu, pemilihan langsung gubernur di Indonesia harus dipertahankan. ${ }^{15}$

15 Pan Mohamad Faiz, "Defending The Direct Gubernatorial Election", http://panmohamadfaiz.com, (diakses pada 15 Maret 2014). 


\section{E. Penutup}

\section{Kesimpulan}

Konstitusi secara tegas menyatakan bahwa kepala daerah dipilih secara demokratis. Rumusan "dipilih secara demokratis" bisa berkonotasi dua yaitu bisa dipilih secara langsung oleh rakyat dan bisa dipilih oleh DPRD sebagai lembaga perwakilan rakyat. Dengan demikian, konstitusi memberikan ruang terbuka kepada pembentuk undang-undang untuk mengatur bagaimana sistem pemilihan kepala daerah yang demokratis. Namun demikian, pemilihan secara langsung merupakan satu-satunya cara yang paling efektif untuk memaknai frasa "dipilih secara demokratis" yang dimuat dalam Pasal 18 ayat (4) UUD 1945.

Dinamika perkembangan pemerintahan daerah juga tidak terlepas dari sejarah sistem pemilihan kepala daerah. Adanya perubahan sistem pemilihan kepala daerah di Indonesia ditandai dengan telah diberlakukannya berbagai peraturan perundang-undangan terkait dengan Pemeritahan Daerah. Dalam konteks sejarah pemilihan kepala daerah, beberapa sistem pemilihan kepala daerah telah dilaksanakan, pertama, pada masa kolonial kepala daerah diangkat oleh pemerintah. Kedua, masa kemerdekaan kepala daerah diangkat oleh Presiden/Mendagri. Ketiga, masa Orde Baru pemilihan kepala daerah dengan cara pencalonan oleh Fraksi di DPRD, kemudian diputuskan dan diangkat oleh Presiden. Keempat, masa Reformasi telah terbit 2 (dua) undang-undang tentang pemerintahan daerah, yakni UU No. 22 Tahun 1999 yang mengatur sistem pemilihan kepala daerah oleh DPRD, yang kemudian diganti oleh UU No. 32 Tahun 2004 yang menentukan sistem pemilihan kepala daerah secara langsung oleh rakyat.
Saat ini, terdapat usulan perubahan sistem pemilihan kepala daerah yang tertuang dalam RUU Pilkada, yaitu yang sebelumnya sistem pemilihan Gubernur secara langsung oleh rakyat dirubah menjadi sistem pemilihan Gubernur secara perwakilan oleh DPRD Provinsi. Sementara untuk sistem pemilihan Bupati/ WaliKota, yaitu tetap mengggunakan sistem pemilihan langsung oleh rakyat. Kemudian untuk mekanisme pemilihan wakil kepala daerah (Wakil Gubernur dan Wakil Bupati/ Walikota) tidak lagi dipilih secara berpasangan dengan kepala daerah, tetapi wakil kepala daerah diusulkan oleh kepala daerah terpilih yang berlatar belakang dari pegawai negeri sipil (PNS). Usulan pemerintah tentang sistem pemilihan Gubernur melalui DPRD yang tertuang pada RUU Pilkada tersebut bukanlah merupakan sebuah kebijakan yang tepat, sehingga dapat mengingkari prinsip demokrasi.

\section{Saran}

Pembentuk undang-undang diharapkan dapat meninjau kembali kebijakannya tentang sistem pemilihan gubernur oleh DPRD yang tertuang dalam RUU Pilkada. Karena pemilihan secara langsung merupakan satu-satunya cara yang paling efektif untuk memaknai frasa "dipilih secara demokratis" yang dimuat dalam Pasal 18 ayat (4) UUD 1945. Selain itu, Pemerintah perlu juga untuk mengambil pelajaran dari sejarah sistem pemilihan kepala daerah mulai dari masa kolonial hingga reformasi yang pernah diterapkan di Indonesia, pengalaman itu cukup memberikan pelajaran bagi Indonesia untuk selanjutnya menentukan sistem pemilihan kepala daerah yang tepat dan tentunya berdasarkan prinsip-prinsip demokrasi. Oleh karena itu, kedepan pembuat undang-undang wajib untuk mengevaluasi jika 
ada kekurangan guna memperbaiki sistem, bukan malah merubahnya. Seperti diketahui bersama, Indonesia baru menerapkan sistem pemilihan kepala daerah secara langsung pada tahun 2005, terhitung baru 10 tahun sistem tersebut diterapkan. Sehingga itu merupakan waktu yang sangat singkat untuk menilai gagalnya sebuah sistem.

\section{DAFTAR PUSTAKA}

\section{Buku}

Assiddiqie, Jimly, Hukum Tata Negara dan Pilar-Pilar Demokrasi, Serpihan Pikiran Hukum, Media dan HAM (Jakarta: Konstitusi press, 2005).

Budiardjo, Miriam, Dasar-dasar Ilmu Politik (Jakarta: PT Gramedia Pustaka Utama, 2010).

Gaffar, Afan, Politik Indonesia; Transisi Menuju Demokrasi (Yogyakarta: Pustaka Belajar, 1999).

Huda, Ni'matul, Dinamika Ketatanegaraan Indonesia dalam Putusan mahkamah Konstitusi (Yogyakarta: FH UII Press, 2011).

Huda, Ni'matul, Hukum Pemerintahan Daerah (Bandung: Penerbit Nusamedia, 2010).

Marzuki, Peter Mahmud, Penelitian Hukum (Jakarta: Kencana Prenada Media Group, 2005).

Projodikoro, Wirjono, Asas-Asas Ilmu Negara dan Politik, Cetakan ke-2 (Bandung: PT. Eresco Jakarta, 1981).

Soekanto, Soerjono dan Sri Mamuji, Penelitian Hukum Normatif Suatu Tinjauan Singkat (Jakarta: Rajawali, 2009).

\section{Makalah / Artikel / Prosiding / Hasil Penelitian}

Asshiddiqie, Jimly, "Struktur Ketata negaraan Indonesia Setelah Perubahan Keempat UUD 1945", (Makalah disampaikan dalam seminar Pembangunan Hukum Nasional VIII, BPHN Departemen Kehakiman dan HAM RI, Denpasar, 14-18 Juli 2003).
Naskah Akademik Tentang Rancangan Undangundang Tentang Pemilihan Kepala Daerah (RUU Pilkada).

Pengantar Redaksi, "RUU Pilkada: Rekayasa Setengah Hati", Jurnal Pemilu dan Demokrasi, Perludem, Edisi 4 November (2012).

Zuhro, R. Siti, "Memahami Demokrasi Lokal: Pilkada, Tantangan dan Prospeknya", Jurnal Pemilu dan Demokrasi, Perludem, Edisi 4 November (2012).

\section{Internet}

Kompas, Paradoks Biaya Politik Mahal, http://cetak. kompas.com/read/2010/07/23/04255481/ paradoks.biaya.politik.mahal, Jum'at, 23 Juli 2010, (diakses pada 27 Januari 2013).

Faiz, Pan Mohamad, "Defending The Direct Gubernatorial Election", http:// panmohamadfaiz.com, (diakses pada 15 Maret 2014).

\section{Peraturan}

Undang-Undang Dasar Negara Republik Indonesia Tahun 1945.

Undang-Undang Tentang Pemerintahan Daerah.

\section{Putusan Pengadilan}

Putusan Mahkamah Konstitusi Nomor 072-073/ PUU-II/2004 tentang Pengujian UU No. 32 Tahun 2004 tentang Pemerintahan Daerah Terhadap UUD 1945 